\title{
Detection of RNA Hydrolysis with Binase by Acridine Orange Fluorescence
}

\author{
A. N. Doynikova ${ }^{a}$ and N. L. Vekshin ${ }^{b, *}$ \\ ${ }^{a}$ Kazan (Volga Region) Federal University, Kazan, 420008 Russia \\ ${ }^{b}$ Institute of Cell Biophysics, Russian Academy of Sciences, Pushchino, Moscow oblast, 142290 Russia \\ *e-mail:nvekshin@rambler.ru
}

Received September 14, 2018; revised March 4, 2019; accepted April 22, 2019

\begin{abstract}
Fluorescence spectroscopy was used to study the specific hydrolysis of ribosomal RNA by binase in aqueous buffer solutions. Acridine orange was used for RNA staining. When the dye was bound to RNA, its fluorescence intensity increased by two times due to the formation of a stable complex. During RNA hydrolysis by binase for 1-20 min, this complex was cleaved, which was accompanied by a nearly twofold decrease in fluorescence. The degree of polarization of the dye fluorescence during hydrolysis was reduced by a factor of 5.5. The hydrolysis reaction was slower at a $\mathrm{pH}$ of 5.0-6.0 than at a $\mathrm{pH}$ of 7.0-8.0, but it proceeded almost until the end. Hydrolysis was slowed with an increase in the ionic strength of the buffer and was suppressed by magnesium ions. The studied reaction can be further used as a convenient, selective, fluorometric method for the detection of single-stranded ribosomal RNA and the study of their properties.
\end{abstract}

Keywords: acridine orange, ribonuclease, binase, single-stranded RNA, RNA hydrolysis, fluorescence spectroscopy

DOI: $10.1134 / \mathrm{S} 0003683819050028$

\section{INTRODUCTION}

Measurement of the RNA concentration in biological samples is an important task. The biochemical methods used for this are too laborious. One of the most simple and highly sensitive methods for RNA detection is staining with fluorescent dyes. However, these dyes usually fluoresce not only when they bind to RNA but also to DNA, proteins, and lipids. Specific hydrolysis with ribonuclease can be used to make the method selective for RNA.

Ribonucleases (RNases) are enzymes that destroy RNA and thereby provide an intracellular balance between the synthesis and hydrolysis of their various types [1]. Binase is a cationic guanyl-specific RNase; it is secreted by Bacillus pumilis (B. intermedius) [2]. It possesses cytotoxicity and the ability to induce selective apoptosis of cancer cells [3, 4] and pandemic influenza A (H1N1) virus [5]. In the binase structure, there are three alpha-helices and two beta-sheets [6]. Binase is an endonuclease that cleaves the phosphodiester bond between the 3'-guanine residue and the 5 'OH-residue of the neighboring nucleotide to form an intermediate, 2',3'c-GMP. The subsequent hydrolysis of 2', 3'c-GMP to 3'-phosphate is highly specific but proceeds slowly, and $2^{\prime}, 3^{\prime} \mathrm{c}-\mathrm{GMP}$ is detected in the reaction mixture within $1 \mathrm{~h}$ [7]. One of the catalytic residues, His 101, is localized on the mobile loop, and the other, Glu72, is located in the protein's beta structure. The residues Phe55 and Tyr102 are part of the substrate-binding site. Guanine bases are bound to this site [8]. The catalytic activity of binase towards synthetic polynucleotides and a high-polymer yeast RNA was previously characterized by standard methods $[9,10]$.

Kinetic studies of RNase functioning under different conditions are one of the most important tools for an understanding of their interaction with RNA. For binase and its homolog, barnase, it has been shown that enzymes are stable over a wide $\mathrm{pH}$ range, from 3 to 10 , with an optimum at $\mathrm{pH} 8.5$, and metal ions are not required for their activity [11]. Binase in solution is capable of forming dimers, which is necessary for efficient RNA hydrolysis [12].

In applied problems, it is possible to determine the RNA content in various biological samples via staining with a fluorescent dye and with binase as a specific sensor. Earlier, acridine orange (AO) dye was used to study the cell cycle, the structure of nucleic acids (NAs), and apoptosis [13], as well as malignant cell growth in vivo and in vitro [14].

The purpose of the work is to use fluorescence to determine the hydrolysis of single-stranded ribosomal RNA with binase under various conditions in vitro with AO dye bound to RNA. 


\section{EXPERIMENTAL}

In the work we used a binase, wild-type guanylspecific RNAse of B. pumilis (EC 3.1.27.3, molecular weight $12.3 \mathrm{kDa}, 109$ amino acid residues, pI 9.5) (Biochemical Plant, Latvia) that was purified and tested for the absence of DNases, high molecular weight, single-stranded yeast rRNA (Serva, United States), fragmented salmon DNA (reagent grade), and analytical grade AO (Diaem, Russia).

We used $0.05 \mathrm{M}$ Tris- $\mathrm{HCl}$ buffer ( $\mathrm{pH}$ 7.0) containing $0.1 \mathrm{M} \mathrm{NaCl}$ and $0.05 \mathrm{M} \mathrm{NaAc}$ (buffer 1) and $0.05 \mathrm{M}$ Tris-phosphate buffer, pH 7.0 (buffer 2).

An AO solution was mixed with one of the buffers at different temperatures and $\mathrm{pH}$ values to a final concentration of $5 \mu \mathrm{M}$. At the used concentration, the AO did not bind to binase and did not inhibit its activity towards RNA. The final binase concentration was $20 \mu \mathrm{g} / \mathrm{mL}$; the final RNA concentration by nucleotide was $260 \mu \mathrm{M}$.

The AO and RNA concentrations were determined on a 5400UF spectrophotometer (PromEcoLab, Russia) at 490 and $260 \mathrm{~nm}$, respectively, and the binase concentration was determined at $280 \mathrm{~nm}$. The formation of an RNA complex with $\mathrm{AO}$ and subsequent hydrolysis with binase was determined from the $\mathrm{AO}$ emission spectra in the range of $500-700 \mathrm{~nm}$ or, depending on the conditions, by the intensity at the spectral maximum $(528-531 \mathrm{~nm})$ with a Cary spectrofluorimeter (Cary, United States) at an excitation wavelength of $490 \mathrm{~nm}$. The reaction of RNA hydrolysis was also detected by the decrease in the degree of polarization of AO fluorescence.

The RNA solutions were mixed with an AO solution, binase was added after binding RNA to the dye. The mixture was incubated for the required time under the given conditions at a predetermined temperature. Then samples were then cooled to room temperature, and we measured the spectra and kinetics of the fluorescence intensity in glass cuvettes $(1 \mathrm{~cm})$ on a Cary spectrofluorimeter or the polarized fluorescence with Glan-Thompson polarizing prisms on a SLM-4800 instrument.

\section{RESULTS AND DISCUSSION}

In ribosomal RNA, about $70 \%$ of nucleotides are modified; in particular, they are methylated and contain the $\mathrm{CH}_{3}$ group in the second position of ribose and in nitrogenous bases. Therefore, they form hairpins; $30 \%$ of the nucleotides are poorly ordered filamentous regions. When interacting with singlestranded, hairpin, and double-stranded NAs, AO monomers fluoresce with green light; AO dimmers fluoresce with red light [15]. In this work, at neutral values of $\mathrm{pH} \sim 7$, the highest intensity of green $\mathrm{AO}$ fluorescence was observed in a complex with singlestranded ribosomal RNA (at $20^{\circ} \mathrm{C}$ ) with a maximum of at $529 \mathrm{~nm}$ (Fig. 1).

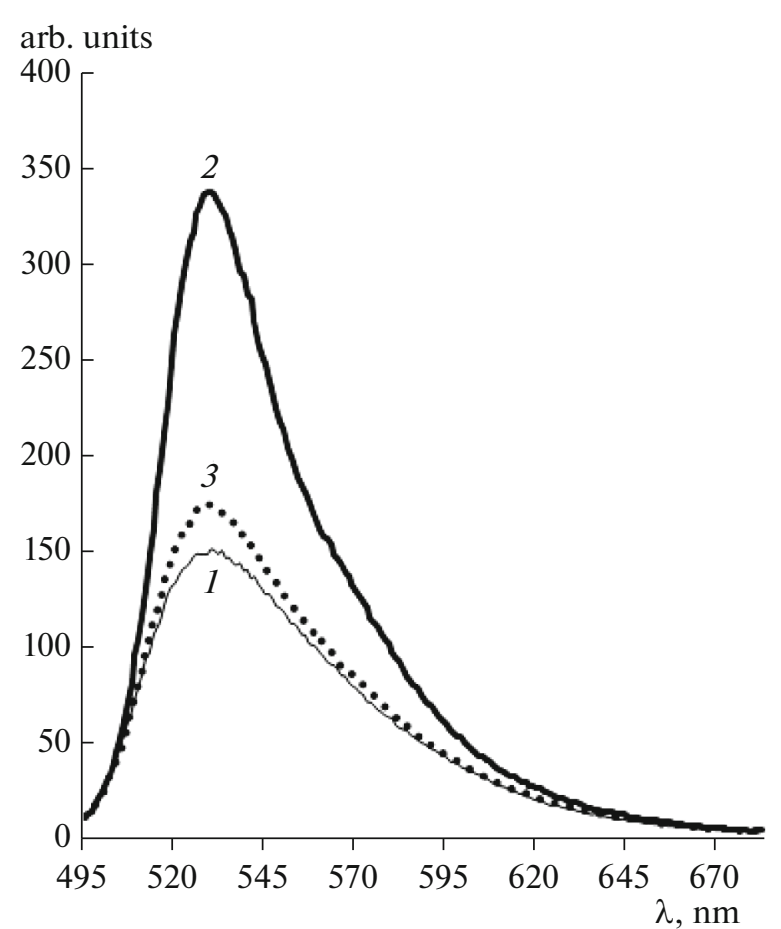

Fig. 1. Fluorescence spectra (in buffer 1 at $\mathrm{pH} 7.0$ and $20^{\circ} \mathrm{C}$ ) of (1) AO, (2) AO-RNA complex, and (3) AO after RNA hydrolysis with binase for $20 \mathrm{~min}$.

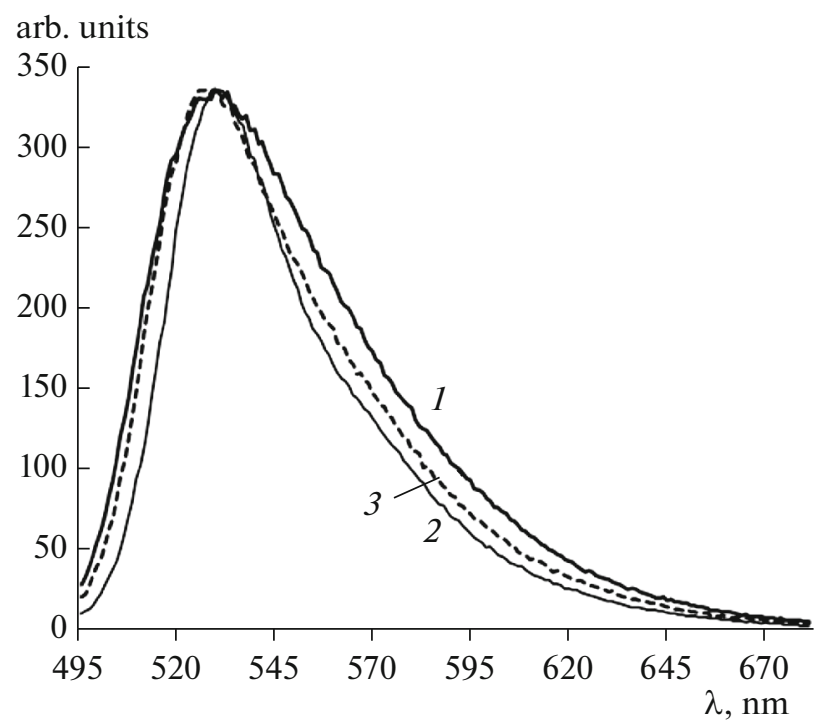

Fig. 2. Normalized at maximum fluorescence spectra of (1) $\mathrm{AO}$ in the aqueous phase, (2) AO with RNA, and (3) fragmented DNA; normalization was performed by the multiplication of two spectra by two coefficients, giving all three spectra the same intensity at the maximum.

Since the spectra of AO with and without RNA were quite similar in shape and position (Fig. 2), this indicated that the dye was inserted not only between the nucleotide planes but in the polar (phosphate) regions of the RNA macromolecule, where it con- 


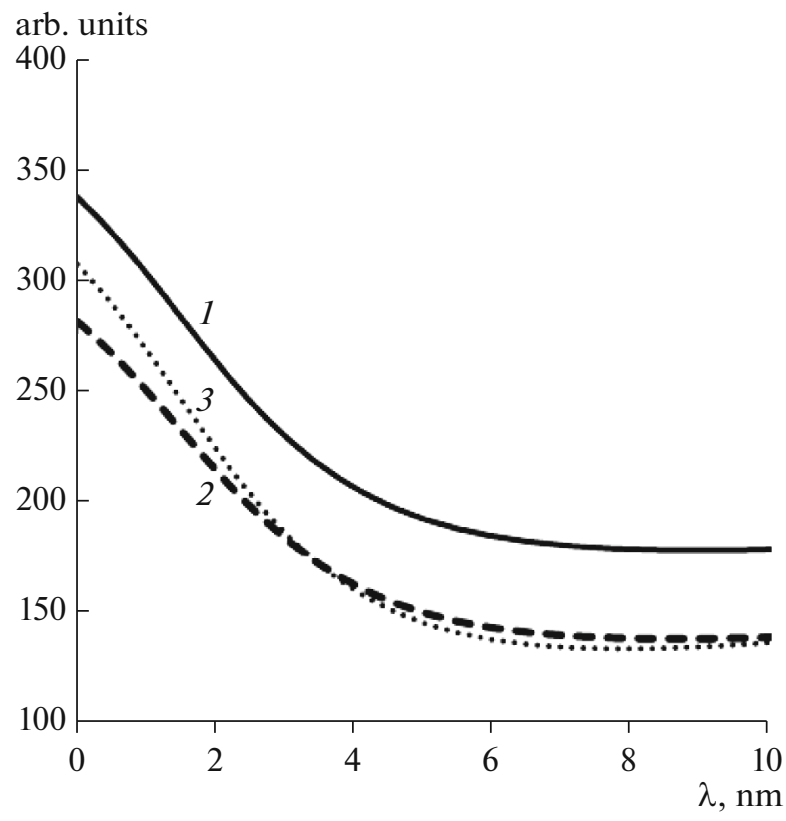

Fig. 3. Fluorescence intensity (arb. units) of an AO-RNA complex after incubation with binase at (1) 20, (2) 37, and (3) $56^{\circ} \mathrm{C}$.

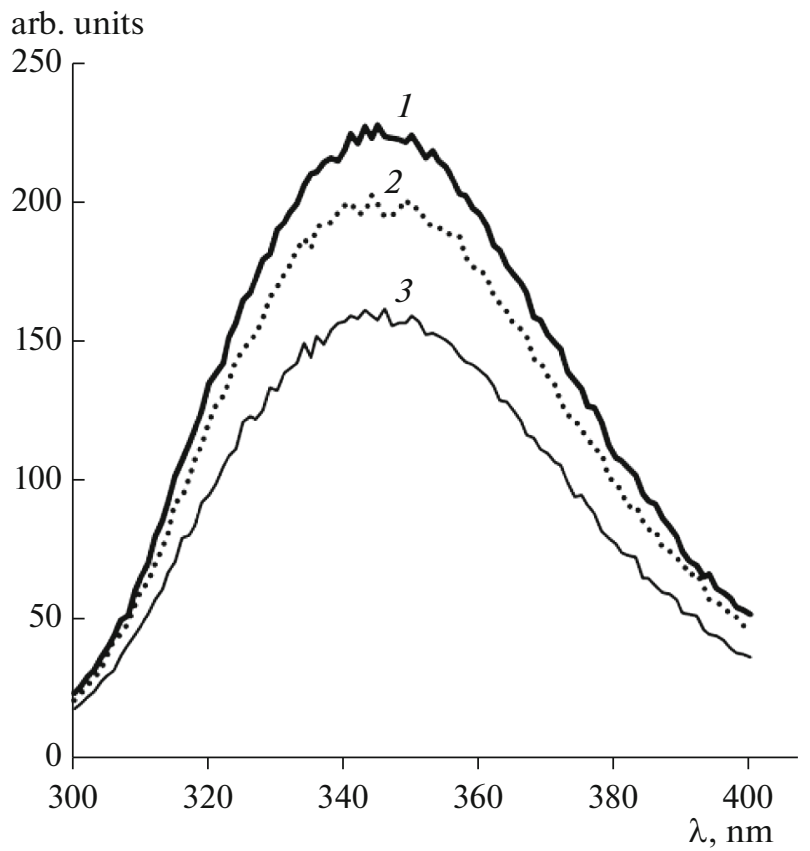

Fig. 4. Fluorescence spectra of (1) starting binase and after heating at $56^{\circ} \mathrm{C}$ for (2) 20 and (3) $120 \mathrm{~min}$.

tacted with water phase. When the dye-to-nucleotide ratio was low $(\sim 1: 50)$, AO did not form dimers (fluorescent in the red region) but a complex with ribosomal RNA; therefore, only green monomeric fluorescence was observed. This indicated that the long
RNA in the solution was folded in some sites and formed double-stranded regions in which the dye was embedded. At the same time, the spectrum of AO in a complex with RNA had a smaller half-width than with fragmented DNA (Fig. 2).

After the introduction of binase into AO solution with rRNA, gradual hydrolysis of RNA was observed (Figs. 1 and 3). An increase in temperature usually leads to a sharp increase in the rate of reactions. However, in the case of hydrolysis with binase, a temperature increase to 37 or $56^{\circ} \mathrm{C}$ caused only a slight acceleration of hydrolysis. In the absence of heating, the hydrolysis proceeded a little more slowly, and the AO fluorescence intensity did not return completely to the initial control level (AO in buffer 1 without RNA). The reaction was carried out faster at higher temperatures ( 37 and $56^{\circ} \mathrm{C}$ ) than at $20^{\circ} \mathrm{C}$ (Fig. 3). It was completed in $5 \mathrm{~min}$, because the fluorescence intensity of the AO-rRNA complex dropped to the initial level (the data were obtained in the "kinetics" mode). The difference in the initial intensities was associated with different temperatures, which affected the fluorescence quantum yield of the dye and its binding. In the case of hydrolysis at room temperature, it required more time, about 15 min (Table 1, Fig. 1). This indicated that the final stage of the reaction of RNA hydrolysis was limiting and weakly dependent on temperature. It is known that a weak dependence on temperature is characteristic of monomolecular enzymatic reactions with an activation energy close to zero (including hydrolysis reactions involving RNases). Since the reaction of RNA hydrolysis with binase takes place only in the formed complexes, not during collisions, it does not greatly depend on temperature.

It can be assumed that there are differences in the intensity of fluorescence of AO and rRNA at room temperature and with heating, because it is more difficult for the dye to intercalate into heated rRNA, which has with a melting point above $56^{\circ} \mathrm{C}$ (the presence of salt in a buffer increases the melting point), since it is strongly uncoiled when heated.

After the heating of binase for $20 \mathrm{~min}$ at $37^{\circ} \mathrm{C}$, the tyrosine band (at $310 \mathrm{~nm}$ ) of the enzyme fluorescence disappeared. When heated to $56^{\circ} \mathrm{C}$, tyrosine fluorescence was also practically absent. A slight $\sim 15 \%$ decrease in tryptophan fluorescence at $350 \mathrm{~nm}$ was observed only when enzyme was heated at $56^{\circ} \mathrm{C}$ for $2 \mathrm{~h}$ (Fig. 4). At the same time, the tyrosine component, which usually appears during protein denaturation in the region of $310 \mathrm{~nm}$ [17], also disappeared. This indicated a very high resistance of bacterial ribonuclease to heat. Even with refluxing for $15 \mathrm{~min}$ at $90^{\circ} \mathrm{C}$, the enzymatic activity of binase was maintained. Thus, the enzyme was very resistant to temperature; it was easily renatured and did not lose activity when heated.

In the study of the effect of $\mathrm{pH}$ on the rate of hydrolysis of the complex of AO with rRNA, the highest fluorescence intensity was observed at $\mathrm{pH}$ 7.0-8.0. As a 
result of hydrolysis with binase, the fluorescence was reduced almost by half within 5 min. Figure 5 shows the changes in the fluorescence intensity of the AOrRNA complex during hydrolysis at different time intervals (data obtained by points). At a $\mathrm{pH}$ of 5.0, the fluorescence intensity of the AO-rRNA complex was 1.5 times lower than at a $\mathrm{pH}$ of 7.0-8.0, even though that the optimum $\mathrm{pH}$ of binase action is 8.5. Thus, at a $\mathrm{pH}$ of 5.0 or 6.0 , a more complete return of the $\mathrm{AO}$ fluorescence intensity to the level of control (within $5 \mathrm{~min}$ ) was observed, i.e., the hydrolysis was carried out to the end, and partial acidic hydrolysis of oligonucleotides may have occurred. At $\mathrm{pH}$ values of 7.08.0 , the hydrolysis reaction also took place for $5 \mathrm{~min}$, but was not complete (Fig. 5), i.e., some of the RNA macromolecules remained unhydrolyzed to short oligonucleotides.

At high ionic strength (when $0.4 \mathrm{M} \mathrm{NaCl}$ was added to buffer 1 or buffer 2), the AO fluorescence intensity decreased as compared with normal conditions. A similar pattern of the kinetics of RNA hydrolysis by the enzyme was observed in both buffer 1 and 2 . However, at a significant increase in the ionic strength of the buffer, the rate of hydrolysis was much lower. To test the effect of buffer 1 on the formation of a complex of AO with RNA (in the presence of sodium chloride and sodium acetate), we used buffer 2 , which was previously applied by other researchers of binase [2-5]. The values of the fluorescence intensity and the rate of RNA hydrolysis were not changed (Table 1, Fig. 5). To assess the effect of magnesium ions and ionic strength, we added $\mathrm{MgCl}_{2}$ (final concentration $3 \mathrm{mM}$ ) and $\mathrm{NaCl}$ (final concentration $0.4 \mathrm{M}$ ). In this case, the

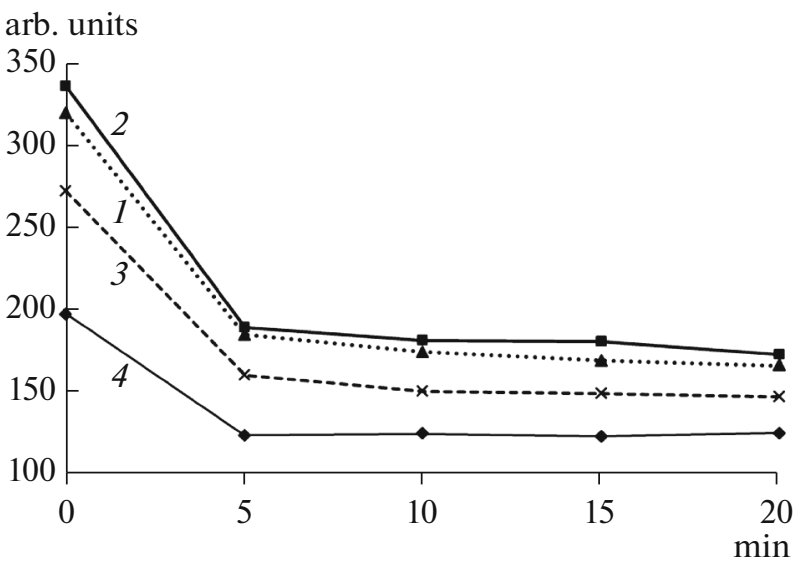

Fig. 5. Dependence of the AO-RNA complex fluorescence intensity (arb. units) measured "by points" after 0,5 , 10,15 , and 20 min at $\mathrm{pH}$ (1) 8.0, (2) 7, (3) 6, and (4) 5 .

fluorescence intensity decreased in comparison with normal conditions (Fig. 1). The selected salts were taken at the indicated concentrations, since these ions are present in the cell in precisely such amounts. A similar pattern of hydrolysis kinetics was observed in both buffer 1 and buffer 2; therefore, buffer 1 was used further.

RNA exists in ribosomes in combination with magnesium ions, which compensate for its negative charge. In this work, the addition of $100 \mu \mathrm{M} \mathrm{MgCl}_{2}$ to an RNA solution at a $\mathrm{pH}$ of 8.0 , which significantly reduced the AO fluorescence (Fig. 6). RNA hydrolysis with binase in the presence of magnesium ions pro-

Table 1. Intensity of AO fluorescence before and after the formation of its complex with RNA in buffer 1 under various conditions

\begin{tabular}{|c|c|c|c|c|c|}
\hline \multirow{2}{*}{$\begin{array}{c}\text { Indicator } \\
\text { Temperature } \\
\text { (pH 7.0) }\end{array}$} & \multicolumn{5}{|c|}{ Fluorescence intensity + binase } \\
\hline & $\mathrm{AO}$ & $\mathrm{AO}+\mathrm{NA}$ & $5 \mathrm{~min}$ & $15 \mathrm{~min}$ & $25 \min$ \\
\hline \multicolumn{6}{|l|}{ RNA } \\
\hline $20^{\circ} \mathrm{C}$ & $150 \pm 1$ & $337 \pm 1.1$ & $192 \pm 2.1$ & $174 \pm 1.3$ & \\
\hline $37^{\circ} \mathrm{C}$ & $135 \pm 1.3$ & $281 \pm 1.3$ & $149 \pm 1.3$ & $142 \pm 1.2$ & \\
\hline $56^{\circ} \mathrm{C}$ & $130 \pm 0.8$ & $307 \pm 0.9$ & $144 \pm 0.9$ & $146 \pm 0.5$ & \\
\hline \multicolumn{6}{|l|}{$\mathrm{pH}\left(\right.$ at $\left.20^{\circ} \mathrm{C}\right)$} \\
\hline pH 5.0 & $150 \pm 0.7$ & $196 \pm 1.9$ & $122 \pm 1.6$ & $123 \pm 1.5$ & \\
\hline pH 6.0 & $140 \pm 1.2$ & $272 \pm 1.9$ & $159 \pm 1.8$ & $148 \pm 1.8$ & \\
\hline pH 7.0 & $150 \pm 1.5$ & $336 \pm 2.5$ & $188 \pm 0.9$ & $180 \pm 1.2$ & \\
\hline pH 8.0 & $135 \pm 0.9$ & $319 \pm 2.3$ & $184 \pm 0.2$ & $168 \pm 0.9$ & \\
\hline \multicolumn{6}{|c|}{ Ions (at $\mathrm{pH} 8.0,20^{\circ} \mathrm{C}$ ) } \\
\hline $100 \mu \mathrm{M} \mathrm{MgCl}{ }_{2}$ & $126 \pm 2$ & $179 \pm 1.9$ & $155 \pm 1.3$ & $141 \pm 1.6$ & $137 \pm 1.3$ \\
\hline $400 \mathrm{mM} \mathrm{NaCl}$ & $109 \pm 1.5$ & $229 \pm 2.6$ & $181 \pm 2$ & $154 \pm 2.1$ & $146 \pm 1.8$ \\
\hline Tris (buffer 2) & $120 \pm 1$ & $224 \pm 1.6$ & $141 \pm 1.4$ & $130 \pm 1.4$ & \\
\hline DNA (control) & $121 \pm 1.2$ & $178 \pm 1.8$ & $179 \pm 2$ & $179 \pm 1.9$ & $179 \pm 1.5$ \\
\hline
\end{tabular}




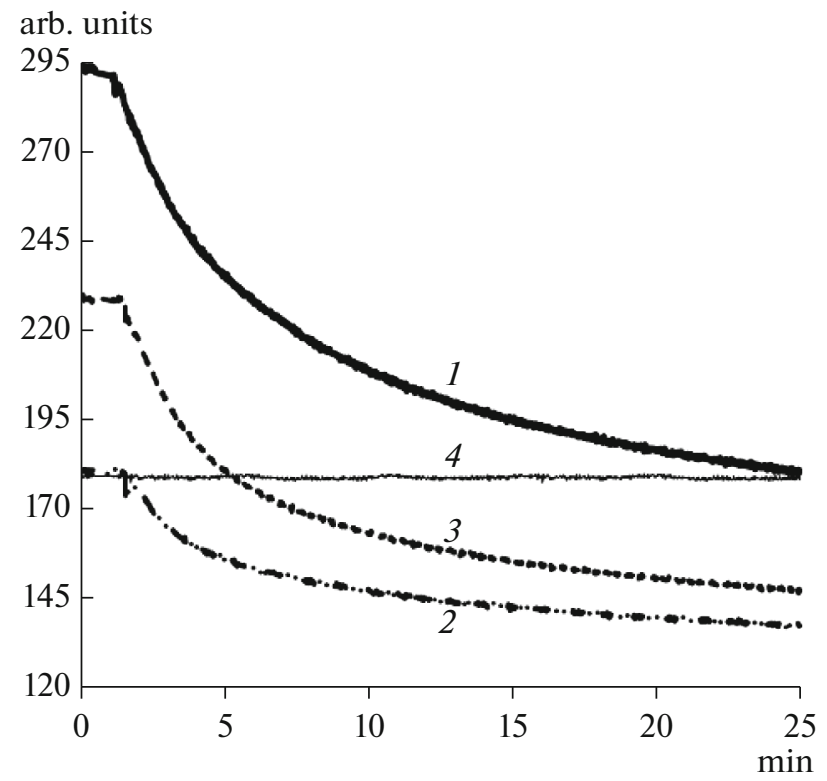

Fig. 6. Kinetics of RNA hydrolysis with binase (in buffer 1 at $\mathrm{pH} 8.0$ and $20^{\circ} \mathrm{C}$ ) detected by (1) AO fluorescence and in the presence of (2) $100 \mu \mathrm{M}$ magnesium chloride or (3) $0.4 \mathrm{M}$ sodium chloride, as well as (4) the absence of fragmented DNA hydrolysis with binase.

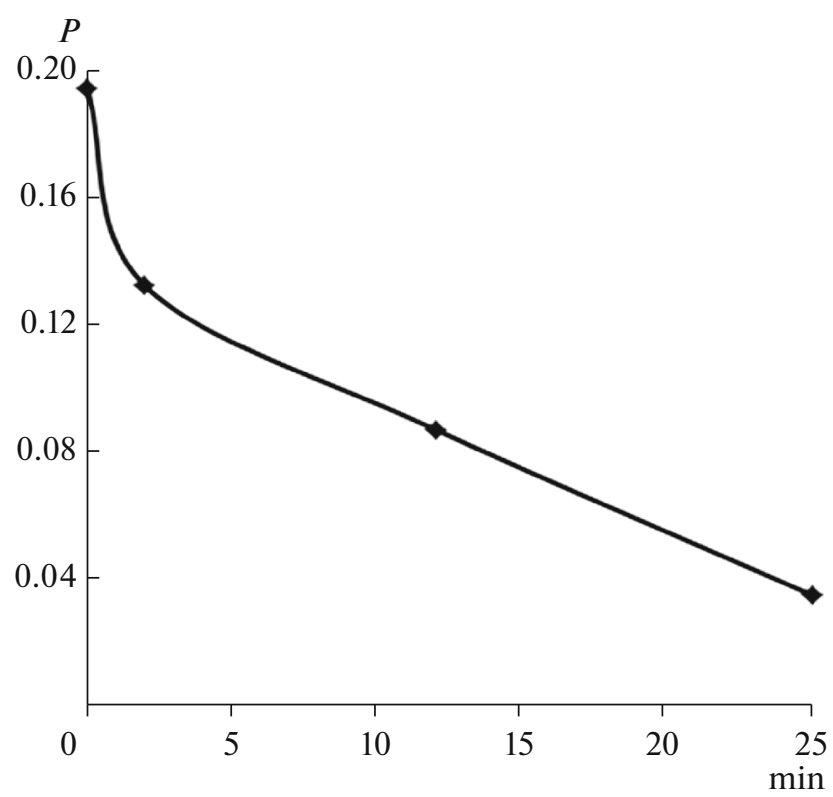

Fig. 7. Decrease in the degree of polarization of AO fluorescence during RNA hydrolysis with binase at a $\mathrm{pH}$ of 7.0 and $20^{\circ} \mathrm{C}$. The excitation wavelength was $510 \mathrm{~nm}$, and the emission wavelength was $540 \mathrm{~nm}$. There were 8 monochromator slits.

ceeded much more slowly. This indicated that the negative charges of the RNA phosphate groups played an important role in the formation of complexes with binase, while magnesium interfered with complexation. It should be noted that we first checked the sta- bility of the AO-RNA complex in the presence of ions (plateau in Fig. 6) and only then added binase.

The metachromatic properties of $\mathrm{AO}$ are used to differentiate DNA and RNA [13-15]. The conditions chosen in this work are specific for the determination of long single-stranded ribosomal RNA that forms double-stranded regions in solution. The effect of ionic strength, the presence of divalent metal cations, and $\mathrm{pH}$ on different RNA and DNA may vary [16].

To test the binase specificity, fragmented salmon DNA, which is also known to form a complex with $\mathrm{AO}$, was used as a control. The formation of an $\mathrm{AO}$ complex with DNA was observed at a $\mathrm{pH}$ of 8.0 and $20^{\circ} \mathrm{C}$ (Fig. 2). However, the fluorescence was lower than in the case of a complex with RNA (Fig. 5). Most importantly, there was no DNA hydrolysis with binase (Fig. 6). Thus, the method was shown to have high specificity; the possibility of "spontaneous" RNA hydrolysis in the absence of binase, including that due to accidental ingress of RNases from the outside, was excluded.

We also applied the polarization fluorimetry method, in which the excitation wavelength was used not in the absorption maximum at $490 \mathrm{~nm}$ but in the long-wavelength region at $510 \mathrm{~nm}$ so that the degree of polarization $(P)$ was as high as possible [17] (the concentrations of the substances were not changed). A six-fold increase in $P$ was observed during AO binding to RNA. This is caused by the redistribution of the dye molecule freely rotating in water into the viscous RNA macromolecule. The subsequent addition of binase reduced polarization by a factor of 5.5 (Fig. 7) almost to the initial level (AO without RNA), which indicated almost complete RNA hydrolysis. Free AO in solution has almost zero $P$ due to its fast rotation, and it is high in combination with the viscous RNA macromolecule. Comparison of the polarization kinetics (Fig. 7) and the intensity kinetics (Figs. 3-5) shows the first of them allowed us to trace the process of RNA hydrolysis until its completion, while the intensity kinetics informed about the initial stages of hydrolysis.

\section{CONCLUSIONS}

Although the developed fluorescent method is less sensitive than the method of dual-color fluorescence cross-correlation spectroscopy of NAs labeled covalently with two fluorophores [18], it has several important advantages: (i) there is no need for a laborious procedure for covalent labeling of RNA or DNA with dyes; (ii) it does not require the use of a correlation microscope and complex dual-color fluorescence spectroscopy techniques; and (iii) the method can be used not only in vitro but also in vivo to study living cells and cell organelles (this will be described in a separate paper).

Thus, in the present work, we proposed a method for RNA determination via fluorescence and polariza- 
tion spectroscopy with AO and a selective "sensor," binase. This method will be further tested as an available alternative for the determination of ribosomal RNA in biological samples.

\section{COMPLIANCE WITH ETHICAL STANDARDS}

The authors declare that they have no conflict of interest. This article does not contain any studies involving animals or human participants performed by any of the authors.

\section{REFERENCES}

1. Shlyakhovenko, V.A., Exp. Oncol., 2009, vol. 31, no. 3, pp. 127-133.

2. Ulyanova, V., Vershinina, V., and Ilinskaya, O., FEBS J., 2011, vol. 278, no. 19, pp. 3633-3643.

3. Ilinskaya, O.N., Dreyer, F., Mitkevich, V.A., Shaw, K.L., Pace, C.N., and Makarov, A.A., Protein Sci., 2002, vol. 11 , no. 10 , pp. 2522-2525.

4. Cabrera-Fuentes, H.A., Aslam, M., Saffarzadeh, M., Kolpakov, A., Zelenikhin, P., Preissner, K.T., and Ilinskaya, O.N., Toxicon, 2013, vol. 69, no. 3, pp. 219226.

5. Shah Mahmud R. and Ilinskaya, O.N., Acta Naturae, 2013, vol. 5, no. 4, pp. 44-51.

6. Reibarkh, M.Ya., Nolde, D.E., Vasilieva, L.I., Bocharov, E.V., Shulga, A.A., Kirpichnikov, M.P., and Arseniev, A.S., FEBS Lett., 1998, vol. 431, no. 2, pp. 250-254.

7. Sokurenko, Yu.V., Zelenikhin, P.V., Ulyanova, V.V., Kolpakov, A.I., Muller, D., and Ilinskaya, O.N., Russ. J. Bioorg. Chem., 2015, vol. 41, no. 1, pp. 37-43.

8. Wang, L., Pang, Y., Holder, T., Brender, J.R., Kurochkin, A.V., and Zuiderweg, E.R., Proc. Natl. Acad. Sci. U. S. A., 2001, vol. 98, no. 14, pp. 7684-7689.
9. Yakovlev, G.I., Moiseyev, G.P., Struminskaya, N.K., Borzykh, O.A., Kipenskaya, L.V., Znamenskaya, L.V., Leschinskaya, I.B., Chernokalskaya, E.B., and Hartley, R.W., FEBS Lett., 1994, vol. 354, no. 3, pp. 305306.

10. Ilinskaya, O.N., Karamova, N.S., Ivanchenko, O.B., and Kipenskaya, L.V., Mutat. Res., 1996, vol. 354, no. 2, pp. 203-209.

11. Takahashi, K. and Moore, S., The Enzymes, New York: Acad. Press, 1982.

12. Dudkina, E., Kayumov, A., Ulyanova, V., and Ilinskaya, O., PLoS One, 2014, vol. 9, no. 12, pp. 1-14.

13. Syasina, T.V., Kozlov, A.V., Bessmel'tsev, S.S., and Udal'eva, V.Yu., in Materialy mezhdunarodnoi konferentsii "Prioritetnye napravleniya razvitiya nauki, tekhnologii i tekhniki", Egipet (Proc. Int. Conf. "Priority Directions in the Development of Science, Technology, and Equipment," Egypt), Sovrem. Naukoemk. Tekhnol., 2011, no. 1, pp. 63-64.

14. Belyaeva, T.N., Salova, A.V., Leont'eva, E.A., Mozhenok, T.P., Kornilova, E.S., and Krolenko, S.A., Tsitologiya, 2009, vol. 51, no. 10, pp. 830-837.

15. Saifitdinova, A.F., Dvumernaya fluorestsentnaya mikroskopiya dlya analiza biologicheskikh obraztsov. Uchebno-metodicheskoe posobie (Two-Dimensional Microscopy for Analysis of Biological Specimens: Study Guide), St. Petersburg: Solo, 2011, 2nd ed.

16. Andreeva, I.S. and Zakabunin, A.I., Biological Sciences, "Colloquium-J.," 2017, no. 2, pp. 8-15.

17. Vekshin, N.L., Photonics of Biopolymers, Berlin: Springer, 2002.

18. Kettling, U., Koltermann, A., Schwille, P., and Eigen, M., Proc. Natl. Acad. Sci. U. S. A., 1998, vol. 95, no. 4, pp. 1416-1420.

Translated by G. Levit 